\title{
Islamic Political Economy: \\ Critical Review of Economic Policy in Indonesia
}

Ropi Marlina, J. Juliana, N. Amalia Adila dan M. Bilal Robbani

STIE Dr. Khez. Muttaqien, and Indonesia University of Education

E-mail: ropi.marlina@stiemuttaqien.ac.id, Julian@upi.edu, nispiamalia@ student.upi.edu, muhbilalrobbani@student.upi.edu

\begin{abstract}
This article is based on a phenomenon of inequality in Indonesia, which is still relatively high. Besides, the current reality shows that the implementation of political economy has not been able to meet the primary needs of each individual. This article aims to describe and elaborate on the concepts and objectives of the Islamic political economy. The qualitative descriptive method is used with a literature review approach with sources from books, journals, news, and other sources relevant to the title. The results of the discussion of this article show that economic politics in the perspective of Islam has a different perspective from capitalists. Islamic Political Economics aims to fulfill each individual's primary needs (food, shelter, and clothing). In implementing the Islamic Political Economy, the state has an important role, either directly or indirectly. As for case studies in Indonesia, regarding aspects of fulfilling food needs, it is ranked 73rd globally with a GHI of 21.9. This is a huge number at a severe level. The number shows that the Indonesian government has not been able to fulfill one of the political goals of Islamic economics, namely the fulfillment of each individual's food. In addition, in terms of security, education and health have not also been well fulfilled. It is expected that this writing will become a reference and add to the treasure of thought regarding the Islamic economy.
\end{abstract}

Keywords. Islamic Political Economy, Primary Needs, Wealth Distribution

\section{INTRODUCTION}

Political economy is a goal to be achieved by every kind of regulation used to solve the regulatory mechanism of various kinds of human affairs (An-Nabhani, 2010). The political, economic system of capitalism and socialism has failed to create social welfare, which brought many mistakes. The mistake that is created explains as making the national income the basis of political economy.

The globalization of the economy and the bubble economy collapsed in various countries, including the United States of America, which first applied the capitalist system. The economy of capitalism also tends to cause unequal differences between the rich and the poor, for the worse, perpetuate poverty (Hasbiullah, 2009).

Political economy in any country was born from the general thoughts concerning nature, human beings, and life. The country built economic policies based on existing realities. Islam sees differently. Islam has its distinctive view of life. The Islamic view was built on the texts of the Qur'an and the Sunnah. Thus, Islam tends to have a distinctive perspective in understanding the problems of life. Islamic economic politics is derived from this distinctive view, namely the Islamic belief. However, these thoughts have not been used as guidelines in solving life problems, especially economics (al-Maliki, 2009).

The politics of Islamic economics speaks of fulfilling the basic needs of each individual, including food, clothing, and shelter. Fulfilling these basic needs of each individual has become the responsibility of the government. The government can fulfill those primary needs through a political economy and non-economic strategy.

The phenomenon that occurs in Indonesia is that inequality is still quite high. The following table can prove the condition. 
Table 1

The Development of Gini Ratio in Indonesia Period of March 2014-March 2018

\begin{tabular}{lccc}
\multicolumn{1}{c}{ Year } & City & Village & City+Village \\
\hline March 2014 & 0,428 & 0,319 & 0,406 \\
September 2014 & 0,433 & 0,336 & 0,414 \\
March 2015 & 0,428 & 0,334 & 0,408 \\
September 2015 & 0,419 & 0,329 & 0,402 \\
March 2016 & 0,410 & 0,327 & 0,397 \\
September 2016 & 0,409 & 0,316 & 0,394 \\
March 2017 & 0,407 & 0,320 & 0,393 \\
September 2017 & 0,404 & 0,320 & 0,391 \\
March 2018 & 0,401 & 0,324 & 0,389 \\
September 2018 & 0,391 & 0,319 & 0,384 \\
\hline Source: Cenca
\end{tabular}

Source: Central Bureau of Statistic (2019)

Inequality in Indonesia itself is measured by the amount of the Gini ratio with a range of numbers $0-1$. The closer to the number 0 , and the better. Table 1.1 explains that the Gini overall ratio has decreased, but it still ranged at 0.4 , and the result is still quite high. The inequality in Indonesia occurs as the distribution of wealth in Indonesia is still not distributed equally. Most of the assets are still held by some of the rich.

This phenomenon shows that the distribution of wealth in Indonesia is not fair enough. The condition can be seen from not evenly distributed fulfillment of the primary needs of each individual in Indonesia.

This study aims to present a general concept, understand the political objectives, introduce the strategy and implementation, provide critical reviews, and state the solutions regarding the Islamic political economy in Indonesia.

The method used in writing this journal is a descriptive qualitative research method with a literature review approach. Sukmadinata (2011) explains that qualitative descriptive research is used to describe and depict existing phenomena, both natural and human engineering, which pay more attention to the characteristics, quality, and the inter-relationship between activities.

The literature review itself contains theoretical descriptions and other research findings and materials obtained from reference materials. It is used as a basis for research activities that are following the selected topic.

\section{LITERATURE REVIEW THEORETICAL FOUNDATION}

\section{The Politics of Economy}

Political economy is ultimately taken from the Greek language, namely policy, which means a city or political unit, and oikonomike which means household management (Heriyono, 2013). Heriyono (2013) adds that these two terms are related to each other in terms of production, finance, and trade with government finance in the financial, financial, and commercial fields.

Deliarnov (2006) and Saskara (2017) explain political economy as a study of social theories and openness. Based on this explanation, political economy discusses the basic problems in social theory, particularly the relationship between politics and economics.

The politic in economy emphasizes the political process related to distribution and production, which Robert Gilpin approved that political economy is intended to discuss political interests that require activities in the economy, particularly costs, and can provide benefits from the activity (Purnomo, 2018).

\section{The Islamic Politic of Economy}

Maghfur (2016) states that the study of politics in the Islamic economy results in the development of Islamic law in-country wealth management policy (at-tasharruf). Technically, Ithe politic in the Islamic economy is better known as the Siyasah Maliyah or Tadakhul ad-Daulah (government intervention). This term was developed by Muhammad Baqr Al-Sadr, who concludes that 
the state intervened in economic activities to ensure the adaptation of Islamic law related to society's economic activities. This country is seen as participating in the Islamic economy, which aims to harmonize the arguments contained in the text. In addition, the country has an obligation to its people regarding social security (At-Tadhamun Al-Ijtima'i), social balance (At-Tawadzun Al-Ijtima'i), and state intervention (At-Tadakhul Ad-Daulah).

Therefore, it can be concluded that the politics of the Islamic economy is related to the country's policies to guarantee the fulfillment of each citizen's basic or primary needs.

\section{PREVIOUS RESEARCH}

The research conducted by Juliana, et al. (2018) entitled The Growth and Equity of Economics in the Perspective of Politics in Islamic Economy shows that there was still unbalance of income equity, which affected citizens to receive low prosperity. The findings from the research show the economic growth according to Islamic Economy is not only related to the material development of life standards. Besides, the ideal economic growth will be able to be created optimally and affect the equity of the economy if it uses the politic of the Islamic economy through the direct and indirect strategies. The research by ALMIZAN (2016) entitled Economy Development in the Perspective of Islamic Economy describes economic development as one of the strategies to achieve the desired goal of the nation. The goal includes how poverty, unemployment, economy, and social disparity are solved to realize humanity's prosperity.

Further, economic development is the development of human maturity where material development could not be avoided and should be supported by spiritual maturity. The most important purpose from the growth of employment added by trustworthy skills will become work with high quality, economic stability, fair distribution, and environment friendly. Islamic comprehensive of economic development has the characteristic of spiritual, moral, material, and the activity tends to be multidimensional. Thus, businesses can balance the factors and eliminate inequality.

\section{RESEARCH METHODOLOGY}

This study used qualitative methods. Chariri (2009) revealed that qualitative research is carried out in certain settings that exist in real life (natural). Furthermore, this method aims to understand and investigate further phenomenon; what happened, why did it happen, and how did it happen? While the used approach was the literature review, where the author tries to examine further the phenomenon with various sources of study, whether uses books or related scientific journals.

\section{DISCUSSION}

\section{The Concept and Basic of Politic of Islamic Economy}

The politics of Islamic economics relates to the guarantee of the basic needs of every individual and the country as the guarantor that must fulfill the individual needs. Islam considers that everyone as a human being whose primary needs must be fulfilled as a whole, whereas at the same time, Islam values humans as people who are mutually bound to each other in a certain interaction according to a certain lifestyle (An-Nabhani, 2010).

The trickle-down effect causes the fallacy of politics towards the economy has become the basis for the number of policymakers who result in national income only received by the minority groups with the specific objectives (Musfidar, 2012).

Thus, the principle or the basic politic of the Islamic economy is the distribution of wealth, not economic growth. The meaning of the distribution of wealth itself is the mechanism of mastering wealth from sources of wealth. This wealth growth will occur naturally from the mastery mechanism. If there is a country that makes the distribution of wealth a principle in the politic of the economy, it does not mean 
they deny the growth of wealth. However, the distribution of wealth itself will automatically encourage wealth growth (al-Maliki, 2009).

\section{The Distribution in Islamic Point of View}

The system of capitalist economic considers that the main problem of the economy is scarcity. The solution offers to increase national production and income.

Unlike the case of a system in the Islamic economy, the main problem of the economy in Islamic economic systems is the distribution how goods and services that can be distributed fairly to each community and fulfill their basic needs. This distribution is the solution to the mistakes created by the capitalist economic system. The Islamic economic system greatly protects the needs of every citizen, both rich and poor. Even the Islamic economic system gives the rich moral responsibility to pay attention to the poor (Kholis, 2011).

Therefore, the Islamic economic system requires the distribution must be based on two conditions, namely freedom, and justice of ownership (Munthe, 2014). Freedom states as the freedom in acting framed by the values of religion and justice (Ahmad, 1998). The value of justice here is based on the word of God Almighty Allah SWT. in Qur'an Surat of Al-Hashr: 7, which means:

"And what Allah restored to His Messenger from the people of the towns - it is for Allah and for the Messenger and for [his] near relatives and orphans and the [stranded] traveler - so that it will not be a perpetual distribution among the rich from among you. And whatever the messenger has given you-take; and what he has forbidden you-refrain from. And fear Allah; indeed, Allah is severe in penalty."

Fair distribution in the Islamic economy has a purpose that wealth does not accumulate in a small portion of society but always circulates in society. Fair distribution guarantees the creation of prosperity to be contributed to a better life (Noor, 2012).

Islam recognizes private ownership rights to property and justifies the ownership of property carried out legally as part of human motivation to fight for their welfare and earth prosperity, as the obligation of a caliph. On the contrary, the Islam perspective does not justify using his assets as freely and unlimitedly as their wish (Noor, 2012).

Therefore, it is clear that individual ownership means realizing authority on someone for the wealth they have by using certain mechanisms. In the end, ownership becomes an individual right determined by sharia (An-Nabhani, 2010).

Realizing that in the assets owned by someone, there are rights of others will directly open up a horizontal relationship and narrows the gap during society between the rich and the poor (Noor, 2012).

Islam justifies personal property but does not justify the accumulation of personal property to the extent that it can damage the social foundation of Islam. Although the balance in meeting individuals' needs still exists, sometimes there is still a large amount of wealth owned by several groups of people (Noor, 2012).

Large amounts of wealth will encourage the owner to have the opportunity to save and help in receiving a large income. However, a threat will emerge from this hoarded money. The amount of money hoarded will result in a decrease in the level of income, increase unemployment, and make many people poor. Therefore, hoarding money is something that must be avoided and solved (An-Nabhani, 2010).

\section{The Purpose of Politic in Islamic Economy}

Islamic economics is an economic system based on the Qur'an and Hadits to meet human needs in the world and the hereafter. Specifically, an-Nabhani explains that sharia laws on economics aim to guarantee the primary needs (clothing, food, and shelter) of all the followers (An-Nabhani, 2010). The welfare of the people will be guaranteed as the politics of Islamic economics has guaranteed the

fulfillment of the basic needs of each person (Juliana, Marlina, Saadilah, \& Maryam, 2018). Each individual is allowed to obtain ownership following the capabilities that they can own. This is an acknowledgment of Islam to human nature in maintaining their life. Individual ownership is limited by state ownership and public ownership. (Amar, 2016).

Islam guarantees public ownership and its use which is planned to be used for public needs. This principle is based on the Sunnah of Prophet Muhammad SAW, who states, "People have the 
same rights over water, grasslands, and fire" (Narrated by Abu Dawud and Ahmad). The Sunnah of Prophet Muhammad requires all industries that have to do with water production, mining materials, and even foodstuffs to be managed by the state. Various kinds of fuels for domestic and industrial purposes should not also be controlled by the private sector (Amar, 2016).

Thus, the politics of Islamic economics aims to ensure the fulfillment of the primary needs of each individual, such as food, clothing, and housing. It is considered to provide opportunities for humans to gain prosperity for their lives (An-Nabhani, 2010).

\section{The Strategy Implementation in Politics of Islamic Economy}

The Authority of the country determines justice in the system of socialism and communism, while individual authority is more advance in the system of the capitalist. Meanwhile, Islam perceives justice comes from the authority and authority of Allah SWT. (Gustiawati, 2014).

Yusuf Qardhawi (1995) explains that justice aims to give every right to their respective owners without overdoing and reducing. Meanwhile, capitalism views the concept of justice based on freedom. Speaking about the fairness of distribution, do not be mistakenly caught up in income leveling as it is impossible to follow Sunnatullah (Gustiawati, 2014).

The distribution strategy in Islamic economics is a direct and indirect mechanism. The direct mechanism is a distribution mechanism in which the country fulfills basic service needs, namely security, education, and health (al-Maliki, 2009).

This is based on the hadits narrated by al-Bukhari, namely "The Imam (head of country) is the administrator of the people. The Imam is responsible for the affairs of his people." (Narrated by AlBukhari). The hadits show the obligation of the leader to fulfill the basic needs of his people.

The principle of Islam that can be used as a pivot is that the highest power belongs only to Allah, and man is created as His caliph on the earth. As His caliph, humans have been created in the best form. All other creations, such as the sun, moon, sky (horizon), have been destined to use humans. Thus, Islam greatly warns of dzalim and ill behavior in the economy (Amar, 2016).

The indirect mechanism is guaranteeing the means to fulfill basic needs for clothing, food, and shelter. The country provides a means for humans to gain prosperity for their lives, one of which is the Islamic supports for humans to work (al-Maliki, 2009).

Generally, this indirect mechanism is carried out by making several points; the obligation to work, the provision of jobs, the obligation of heirs, neighbors' responsibility, and subsidies for Baitul Mal (Juliana, Marlina, Saadilah, \& Maryam, 2018).

\section{The Review towards Political Regulations of Economy in Indonesia according to Islamic \\ Perspective}

The Indonesian government still tries to meet existing food needs in Indonesia by increasing supply through increasing rice production and developing higher-value crops. However, this strategy proved ineffective as even though Indonesia is experiencing good economic growth, there are still 19.4 million citizens who cannot meet their daily food needs (Ika, 2018).

The condition explained above could occur due to the fulfillment of food needs for the Indonesian people is imported from abroad or called import. According to Enny Sri Hartati, Director of the Institute for Development of Economics and Finance (Indef), import dependence shifted to meet basic food needs. If this import policy could not be minimized, then the ideals of food independence would be difficult to be conducted (Rahayu, 2018).

In Indonesia, the Food Security Index or IKP is used to see the condition of food security. This index comprises three dimensions: food availability, food affordability/access, and food utilization. These dimensions are divided into several aspects, namely aspects of food sufficiency, aspects of physical, economic, and social affordability, aspects of intake adequacy, and aspects of water quality (Badan Pusat Statistik, 2015).

In 2018, the global food security index of Indonesia had increased from all aspects. The graph below depicts the condition. 


\section{Figure 1 \\ The Global Food Security Index of Indonesia \\ Year 2012-2018}

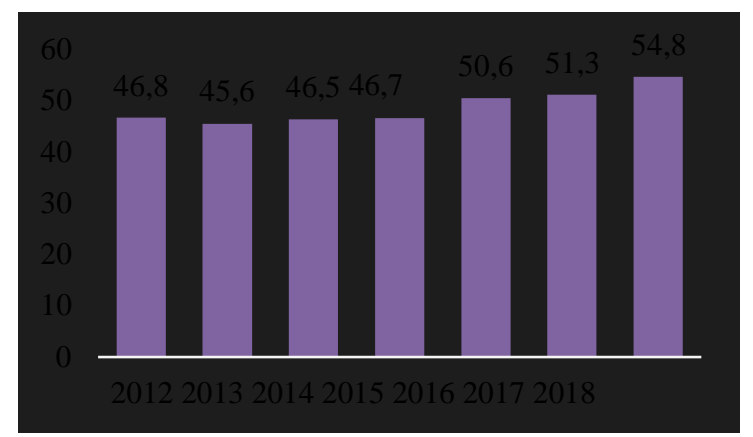

Source: The Economist Intelligence Unit (2018)

The global food security index in Indonesia increased, although not too significant. In 2018 with a score of 54.8 from all aspects of this country, Indonesia ranked 65 in the world and fifth place in ASEAN level. The food security of Indonesia from the affordability aspect scored 55.2, which ranked 63 out of 113 countries. As for the aspect of availability, I gained a score 58.2 and ranked 58. The aspect of quality and security scored 44.5 and ranked 84 . Then, natural resources scored 43.9 and ranked 111 (www.katadata.co.id, 2018).

In addition, the Global Hunger Index (GHI) 2018 reports that the issue of hunger in Indonesia ranked 73 in the world with the GHI index value of 21.9 or at a serious level (Nandini, 2019).

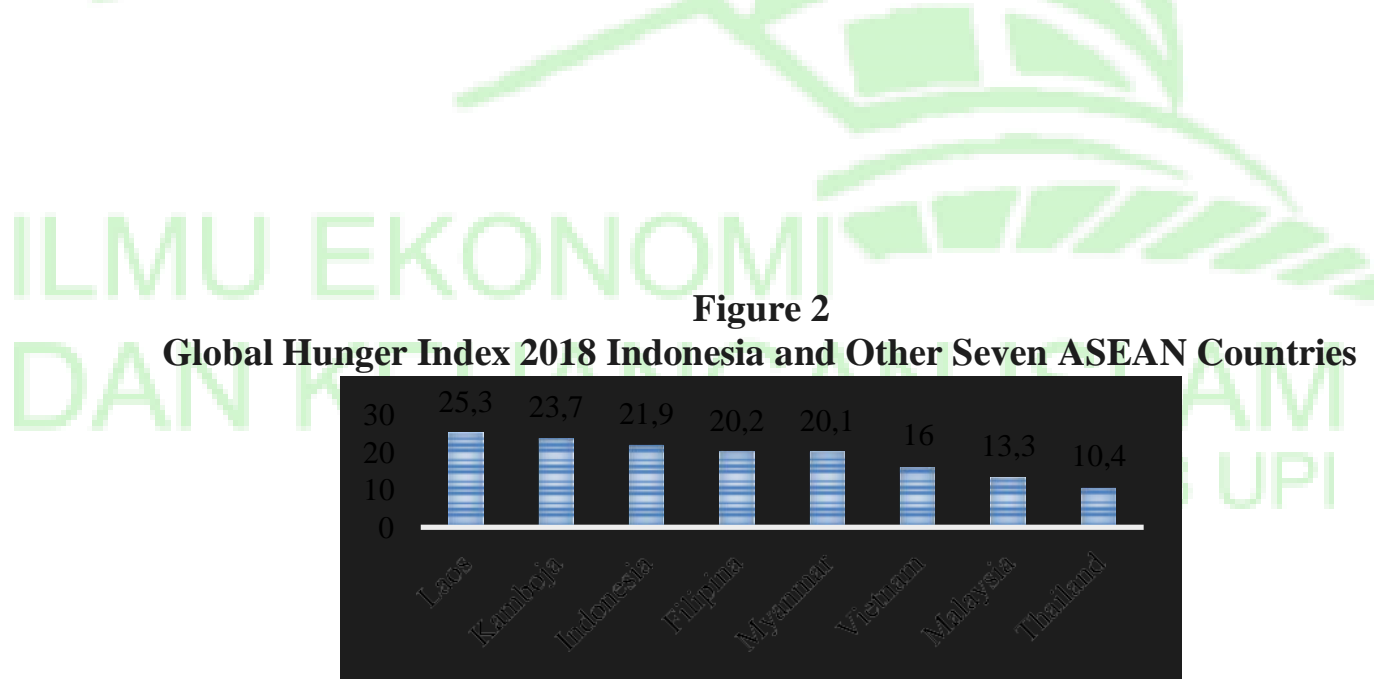

Source: www.globalhungerindex.org (2019)

When Indonesia being compared with seven other ASEAN countries, Indonesia placed at the highest three. The rank shows that the Indonesian government failed to meet the food needs of the Indonesian people.

Fulfilling food needs in Indonesia should increase supply through increasing rice production and related to how food is distributed among the community. Food distribution is not about income leveling because the principles of fairness for socialism, capitalism and Islam are very different.

There are strategies provide by Islam in increasing food security. Food security can be realized through optimizing agricultural land to be more productive and prohibiting feudalism ( Juliana, Firmansyah \& Bangkit, 2016) 
The act for guaranteeing the facilities to obtain these basic needs provides jobs for the community and subsidizes directly from Baitul Mall. In addition, Islam guarantees the people's rights and safeguards the people's assets with guarantees based on the syara' laws. Thus, people do not have to think about education, health, and security as the country has guaranteed the needs of these services. It is different from nowadays condition where many people are burdened by basic needs which are not guaranteed by the country.

\section{CLOSING}

\section{Conclusion}

The politics of Islamic economics guarantees fulfilling the basic or primary needs of each individual from the country. The principle or basis of the politics of the Islamic economy is the distribution of wealth fairly and evenly, not economic growth as adopted by capitalism or socialism.

The politics of the Islamic economy encourages people to enjoy halal sustenance and take various living pleasures according to their abilities. Therefore, the politics of the Islamic economy aims to guarantee the fulfillment of the primary needs, including food, clothing, and shelter. It also aims to provide opportunities for humans to gain prosperity for their lives.

The distribution strategy in Islamic economics is a direct and indirect mechanism. The direct mechanism is a distribution mechanism in which the country fulfills basic service needs, namely security, education, and health. It means to fulfill basic needs for clothing, food, and shelter. The country provides a means for humans to gain prosperity for their lives, one of which is the Islamic motivation for humans to work.

The data shown shows that the Indonesian government has not been able to meet the food needs of the Indonesian people. The fulfillment of food needs in Indonesia should increase supply through increasing rice production and related to how food is distributed among the community. Food distribution is not about income leveling as the principles of fairness for socialism, capitalism, and Islam are very different.

The Islamic strategy in increasing food security is by guaranteeing the means to obtain these basic needs, namely by providing jobs for the community and subsidies directly from the Baitul mall. In addition, Islam guarantees the people's rights and safeguards the people's assets with guarantees based on the syara' laws. Thus, people do not have to think about education, health, and safety because the country has guaranteed these needs.

\section{Suggestion}

The writer suggests that research on the topic of growth and its impact on development equity in the perspective of Islam can continue to be studied further. Especially research that is related to the model and its impact. Remembering the research conducted by the writer still insists on a theoretical literature review.

\section{REFERENCE}

Ahmad, Z. (1998). Al-Qur'an: Kemiskinan dan Pemerataan Pendapatan. Yogyakarta: Dana Bhakti Prima Yasa.

Akhmadi, S., \& Kholish, A. (2016). Prinsip-Prinsip Fundamental Ekonomi Islam. Jurnal Ekonomi Islam (Islamic Economics Journal) Vol. 4 No. 1, 97-118.

Al-Maliki, A. (2009). Politik Ekonomi Islam. Bogor: Al-Azhar Press.

Almizan. (2016). Pembangunan Ekonomi dalam Perspektif Ekonomi Islam. MAQDIS: Jurnal Kajian Ekonomi Islam, 204-222.

Amar, F. (2016). Ekonomi Islam Suatu Pengantar. Jakarta: UHAMKA Press.

An-Nabhani, T. (2010). Sistem Ekonomi Islam: An-Nizhamul-Iqtishadi fi al-Islam. Bogor: Al-Azhar 
Press.

Badan Pusat Statistik. (2019). Kemiskinan dan Ketimpangan. Retrieved from Badan Pusat Statistik: https://www.bps.go.id/subject/23/kemiskinan-dan-ketimpangan.html

Badan Pusat Statistik. (2015, Mei 6). Indeks Ketahanan Pangan. Retrieved from Badan Pusat Statistik: https://www.bps.go.id/news/2015/05/06/110/indeks-ketahanan-pangan.html

Beik, I. S. (2006). Artikel tentang Islam dan Keadilan Ekonomi. Makalah Formal.

Chariri, Anis. 2009. "Landasan Filsafat dan Metode Penelitian Kualitatif”, Paper disajikan pada Workshop Metodologi Penelitian Kuantitatif dan Kualitatif, Laboratorium Pengembangan Akuntansi (LPA), Fakultas Ekonomi UniversitasDiponegoro Semarang, 31 Juli - 1 Agustus 2009

Deliarnov. (2006). Ekonomi Politik. Jakarta: Erlangga.

Gustiawati, S. (2014). Langkah Strategis Optimalisasi Sistem Ekonomi Syariah. Salam: Jurnal Filsafat dan Budaya Hukum.

Hasbiullah. (2009). Krisis Ekoomi Hlobal dan Kegagalan Kapitalisme. Jurnal Ilmu Ekonomi Studi Pembangunan.

Heriyono. (2013). Ekonomi Politik dalam Bisnis. Jurnal Ekonomi.

Holis, M. (2016). Sistem Distribusi dalam Perspektif Ekonomi Islam. Jurnal Perbankan Syariah, 1.

Ika, A. (2018, April 3). 19,4 Juta Orang Indonesia Tidak Dapat Memenuhi Kebutuhan Pangan. Retrieved from Kompas: https://ekonomi.kompas.com/read/2018/04/03/140000126/19-4-jutaorang-indonesia-tidak-dapat-memenuhi-kebutuhan-pangan?page=all

Juliana, Marlina, R., Saadilah, R., \& Maryam, S. (2018). Pertumbuhan dan Pemerataan Ekonomi Perspektif Politik Ekonomi Islam. Amwaluna, 2.

Juliana, Firmansyah \& Bangkit (2016). Telaah Pemikiran Ekonomi Islam : Yahya Bin Adam Al-Qarashi ( \pm 140 H/755 M - 203 H/818 M). Ekspansi. Vol. 8, No. 1, Hal. 77 - 85

Kholis, N. (2011, Februari). Politik Ekonomi Islam di Indonesia Era Reformasi. Retrieved from Research https://www.researchgate.net/publication/326835065_Potret_Politik_Ekonomi_Islam_di_Indon esia_Era_Reformasi

Komariah, A., \& Satori, D. (2011). Metode Penelitian Kualitatif. Bandung: Alfabeta.

Maghfur, I. (2016). Peran Politik Ekonomi Islam dalam Melaksanakan Globalisasi Masyarakat Ekonomi ASEAN (MEA). Jurnal Hukum Islam.

Munthe, M. (2014). Konsep Distribusi dalam Islam. Jurnal Syariah.

Musfidar, M. (2012). Faktor-Faktor Yang Mempengaruhi Ketimpangan Distribusi Pendapatan di Sulawesi Selatan Tahun 2001-2010.

Nandini, W. (2019, Januari 23). Kelaparan di Indonesia Perlu Perhatian. Retrieved Mei 9, 2019, from Katadata.co.id: https://katadata.co.id/grafik/2019/01/23/kelaparan-di-indonesia-perlu-perhatian

Noor, R. A. (2012). Kebijakan Distribusi Ekonomi Islam dalam Membangun Keadilan Ekonomi Indonesia. Jurnal Islamica, Vol. 6, No. 2, 321.

Purnomo, E. P. (2018). Pendekatan Ekonomi Politik dalam Mekanisme Pasar. Teori Politik dan Pemerintahan.

Qardhawi, Y. (1995). Peran dan Nilai Moral Dalam Perekonomian. Jakarta: Rabbani Press. 
Rahayu, Y. A. (2018, April 18). Ironis, Pemenuhan Kebutuhan Pangan Indonesia Dipenuhi Dari Impor. Retrieved from Merdeka: https://www.merdeka.com/uang/ironis-pemenuhan-kebutuhan-panganindonesia-dipenuhi-dari-impor.html

Rahman, A. (1995). Doktrin Ekonomi Islam. Yogyakarta: Dana Bakti Wakaf.

Rahmawaty, A. (2013). Distribusi dalam Ekonomi Islam. Equilibrium, 1.

Saskara, I. A. (2017). Mengenal Ekonomi Kelembagaan. Denpasar: ESBE.

Sukmadinata, N. S. (2011). Metode Penelitian Pendidikan. Bandung: Rosadakarya.

The Economist Intelligence Unit. (2018). Retrieved from The Economist Intelligence Unit: http://www.eiu.com/home.aspx

www.katadata.co.id. (2018, November 1). Ketahanan Pangan Indonesia Menunjukkan Perbaikan.

Retrieved from Katadata.co.id:

https://databoks.katadata.co.id/datapublish/2018/11/01/ketahanan-panganindonesiamenunjukkan-perbaikan

www.globalhungerindex.org. (2019, Mei 9). Global Hunger Index 2018. Retrieved from Global Hunger Index: https://www.globalhungerindex.org/ 